\title{
Author Correction: Checkpoint blockade immunotherapy reshapes the high-dimensional phenotypic heterogeneity of murine intratumoural neoantigen-specific CD8 ${ }^{+} \mathrm{T}$ cells
}

\author{
M. Fehlings (1) ${ }^{1}$, Y. Simoni ${ }^{1}$, H.L. Penny ${ }^{1}$, E. Becht ${ }^{1}$, C.Y. Loh ${ }^{1}$, M.M. Gubin², J.P. Ward², S.C. Wong (1) ${ }^{1}$, \\ R.D. Schreiber ${ }^{2} \&$ E.W. Newell (i) ${ }^{1}$
}

Correction to: Nature Communications; https://doi.org/10.1038/s41467-017-00627-z; published online: 15 Sep 2017

The original version of this Article omitted a declaration from the competing interests statement, which should have included the following: 'R.D.S. is a cofounder, stock holder, and scientific advisory board member of Jounce Therapeutics and Neon Therapeutics, and a member of the scientific advisory boards of BioLegend, Constellation, Lytix, and NGM. He also received research funding from Janssen and Agios.'. This has now been corrected in both the PDF and HTML versions of the Article.

Published online: 26 July 2018

Open Access This article is licensed under a Creative Commons Attribution 4.0 International License, which permits use, sharing, adaptation, distribution and reproduction in any medium or format, as long as you give appropriate credit to the original author(s) and the source, provide a link to the Creative Commons license, and indicate if changes were made. The images or other third party material in this article are included in the article's Creative Commons license, unless indicated otherwise in a credit line to the material. If material is not included in the article's Creative Commons license and your intended use is not permitted by statutory regulation or exceeds the permitted use, you will need to obtain permission directly from the copyright holder. To view a copy of this license, visit http://creativecommons.org/licenses/by/4.0/.
}

(C) The Author(s) 2018

\footnotetext{
${ }^{1}$ Agency for Science, Technology and Research (A*STAR), Singapore Immunology Network (SIgN), 8 A Biomedical Grove, Singapore 138648, Singapore. ${ }^{2}$ Department of Pathology and Immunology, School of Medicine, Washington University in St. Louis, 660 South Euclid Avenue, St. Louis, MO 63110, USA. Correspondence and requests for materials should be addressed to E.W.N. (email: evan_newell@immunol.a-star.edu.sg)
} 